\title{
Production of Single Cell Protein from Date Waste
}

\author{
Mohamed Al-Farsi ${ }^{1^{*}}$, Alaa Al Bakir ${ }^{2}$, Hassan Al Marzouqi $i^{3}$ \\ and Rejoo Thomas $^{2}$ \\ ${ }^{1}$ Food \& Water Lab. Center, Ministry of Regional Municipalities \& Water Resources, Muscat, \\ Oman \\ ${ }^{2}$ R\&D Section, Al Foah Company, Al Ain, UAE \\ ${ }^{3}$ R\&D Department, Abu Dhabi Food Control Authority, AD, UAE
}

Keywords: single cell protein; date's waste; fungal strains; protein, amino acids

\begin{abstract}
This study aimed to utilize the waste of date's industry to produce single cell protein. Five fungal strains were evaluated and the production conditions were optimized. A. oryzae was selected as the optimum strain due to its vigorous growth and high protein production. Ammonium sulfate at $0.8 \%$ was the best source of nitrogen for the selected strain, $\mathrm{pH}$ at 5.5 and the medium ratio of $75 \mathrm{~g}$ in $250 \mathrm{ml}$ flask were the best for growth. The single cell protein produced has a good source of nutrition, as the ratio of essential to the total amino acids was $46 \%$. These results benefit establishing large-scale production to produce single cell protein from date's waste which creates a source of income to this sector and prevent pollution from such waste.
\end{abstract}

\section{Abbreviations \\ Single cell protein (SCP); American Type Culture Collection (ATCC); Potato dextrose agar (PDA); Peptone yeast extract glucose agar (PYG); Dates waste agar (DWA).}

\section{Introduction}

Single cell protein (SCP) is dried cell of microorganisms, which used as protein supplement in human foods and animal feeds. The SCP is cheap and competes well with other source of protein and may provide good nutritive value. Besides high protein content (60-82\%), SCP contains fat, carbohydrates, vitamins and minerals [1,2]. SCP also rich in essential amino acids like lysine and methionine which are limiting in most plant and animal foods [3]. With increase in population and worldwide protein shortage, the use of SCP as a food and feed is more needed [4]. A number of agricultural and agro-industrial waste products have been used for production of SCP, including orange waste, mango waste, cotton stalks, kinnow-mandarin waste, barley straw, corn cops, rice straw, corn straw, onion juice and sugar cane bagasse [5], cassava starch [6], wheat straw [7], banana waste [8], capsicum powder [9] and coconut water [10].

Date syrup production end with waste consist of date fiber and seed. According to Al-Farsi et al [11], the production of date syrup will end with 59\% syrup, $23 \%$ press cake and $12 \%$ seed. Therefore, for instance Al Baraka Dates Company in Dubai, UAE produced 4000 tons of date syrup in the year 2016 [12], this production will end with $1560 \mathrm{~kg}$ of press cake, which can be used for SCP production. Al Farsi et al [11] reported the composition of the syrup waste for three varieties, their protein ranged between 3.6-5.2\%, fat between 1.4-2.2\% and carbohydrates between $81.9-83.3 \%$. The usage of such wastes as a sole carbon and nitrogen source for production of SCP by microorganisms could be simply attributed to their presence in nature on large scale and their cheap cost. Also, utilization of such waste prevents pollution problems and sanitary hazard as well as creating another source of income to this sector. 
Different type of microorganisms can be used for SCP production, such as algal, bacteria, fungi and yeast. The microorganisms used for SCP should be low in nutritional requirements, rapid growth rate, stability during growth, non-pathogenic, low nucleic acid content, non-toxic and good digestibility [13]. While the substrate should be non-toxic, abundant, non-exotic, cheap and able to support rapid growth of organisms resulting in high quality of biomass [14]. During microorganism process for conversion of lignocellulosic wastes into feed, at least one of the three objectives must be reached: 1- An increase in the protein level 2- An increase in digestibility 3- An increase in the essential amino acids [15].

In this work five different fugal strains were evaluated for SCP production from date's syrup waste and the medium condition of the selected strain was optimized for maximum production. This study could be the first research on utilizing dates waste to produce SCP, as no other studies found in this area.

\section{Materials and Methods}

\section{Dates waste}

The dates waste used in this study was procured from Al Foah Company, Al Ain, UAE. This is a by-product of date's syrup production consists of date fiber and seed, which packed in polyethylene bags and stored in $-30^{\circ} \mathrm{C}$ until used.

\section{Fungal Strains}

Five fungal strains were obtained from American Type Culture Collection (ATCC, Manassas, Virginia, USA) based on their characteristics as SCP producers and capability of utilizing lignocellulosic by-products. The strains were Trichoderma reesei (ATCC 13631), Fusarium venenatum (ATCC 20334), Thermomyces lanuginosus (ATCC 34626), Aspergillus oryzae (ATCC 14895) and Fusarium graminearum (ATCC 20333). All cultures were processed according to the specific directions of ATCC.

\section{Culture Media}

Two types of media were used for maintenance and routine subculture including:

1- standard ATCC recommended media for freeze dried culture which were as follows:

- $\quad$ potato dextrose agar (PDA) for Trichoderma reesei and Fusarium graminearum.

- malt agar medium (ATCC 323) for Fusarium venenatum

- malt extract agar medium (ATCC 325) for Aspergillus oryzae

- peptone yeast extract glucose agar (PYG, ATCC 663) medium for Thermomyces lanuginosus

2- Dates waste agar (DWA) used as production medium for fungal strains. The medium contains $25 \%$ date waste, $2 \%$ agar, $0.3 \%$ ammonium sulfate and $72.7 \%$ water. The $\mathrm{pH}$ was kept at the natural date fibers at 5.3.

\section{Strain Selection}

The five fungal strains were grown on DWA after autoclaving the medium in $250 \mathrm{ml}$ flasks at $121{ }^{0} \mathrm{C}$ for $15 \mathrm{~min}$ (duplicates). The inoculation was carried out by spore suspension with absorbance of 1.00 at $600 \mathrm{~nm}$ and surface fermentation was conducted under static condition at $25{ }^{0} \mathrm{C}$, except Thermomyces lanuginosus, which was incubated at $45{ }^{0} \mathrm{C}$ for 120 hrs. The biomass and growth medium were dried at $70{ }^{\circ} \mathrm{C}$ until constant weight, ground to fine powder and analyzed for protein content. The cultures were stored at - $36{ }^{0} \mathrm{C}$ until processed for culturing. 


\section{Determination of Optimal Production Conditions}

- Optimal nitrogen source: Ammonium chloride, ammonium sulfate and urea were used at $0.2 \%$ level in the growth medium DWA with a control containing no added nitrogen.

- Optimal concentration of nitrogen source: The selected nitrogen source was added to the growth medium DWA at $0,0.2,0.4,0.6,0.8$ and $1.0 \%$.

- Optimal medium weight to flask volume: The production medium DWA was dispensed in 250 $\mathrm{ml}$ flasks at 45, 60, 75, and $90 \mathrm{~g} /$ each flask prior to sterilization and inoculation with the selected strain spore suspension, incubated and processed as described above.

- Optimal Initial $\mathrm{pH}$ : The $\mathrm{pH}$ of the DWA medium was adjusted by $1 \mathrm{~N}$ HCL at 4.0, 4.5, 5.0, 5.5, 6.0 and 6.5 prior to sterilization.

\section{Protein Determination}

Protein content of SCP was determined by analyzing the powdered samples for nitrogen content in CHNSO analyzer (HEKAtech GmbH, Wegberg, Germany) and the obtained values were converted to protein by the factor 6.25 .

\section{Determination of amino acids}

Amino acid content of dates fiber and SCP were determined according to the Official European Union regulation No 152/2009 [16]. This method determines free and total amino acids (peptide bound and free) using amino acid analyzer (Shimadzu, Japan).

\section{Statistical analysis}

Results were expressed as mean \pm standard deviation on a wet weight basis. Statistical significance (t-test: two-sample equal variance, using two-tailed distribution) was determined using the Microsoft Excel Statistical Data Analysis. Differences at $\mathrm{p}<0.05$ were considered to be not significant.

\section{Results and discussion}

\section{Strain selection}

The DWA medium which used as a medium for fungal growth was simple to prepare and has clear economic potential in large scale part of the project. No hydrolyses treatment been used for this media, as the date fiber macerated from dates syrup processing. The presence of sugar in date fibers along with complex lignocelluloses components has induction effect on production of essential carbohydrate hydrolyses. Figure 1 present growth of the five fungal strains and figure 2 shows the protein content produced by these fungal strains. It's clearly shows the vigorous growth of A. oryzae compares to other fungi, also the protein content produced by A. oryzae was significantly higher than others. Based on the obtained results (vigorous growth and high protein) A. oryzae was selected as the optimum strain for DWA and used for optimal production condition. Jin et al [17] found A. oryzae as the best option to produce SCP from starch waste water. Also, Ahmadi et al [18] reported 57\% protein content produced by A. oryzae from rice bran. 


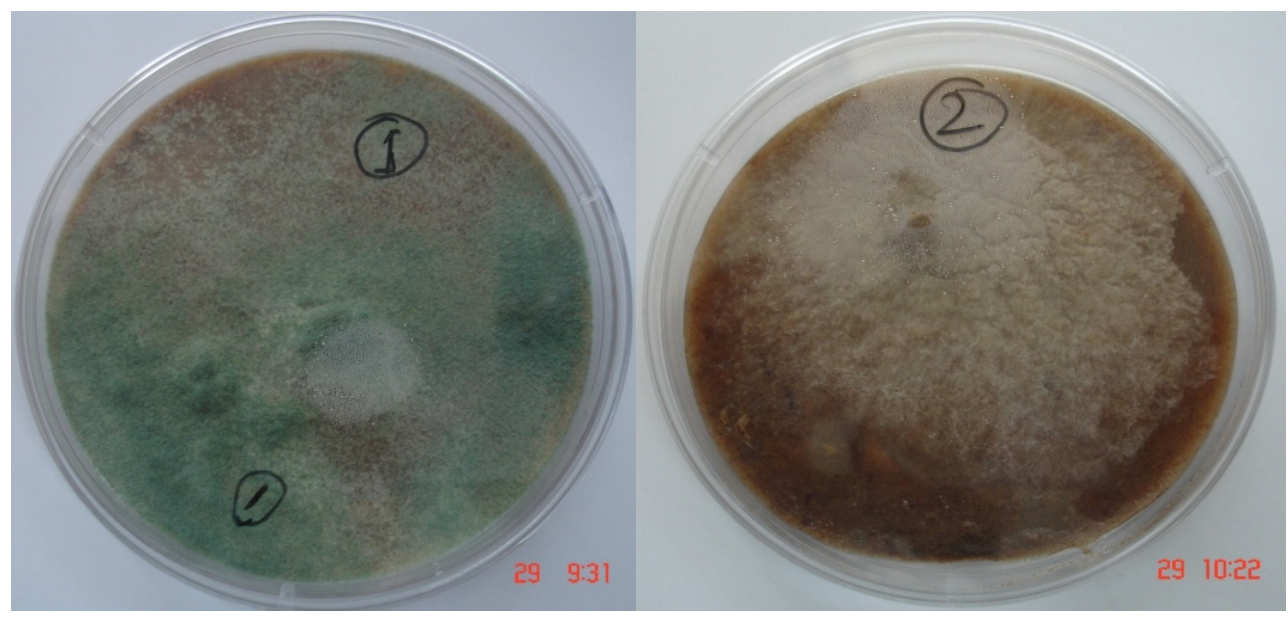

\section{Trichoderma reesei}

Fusarium venenatum

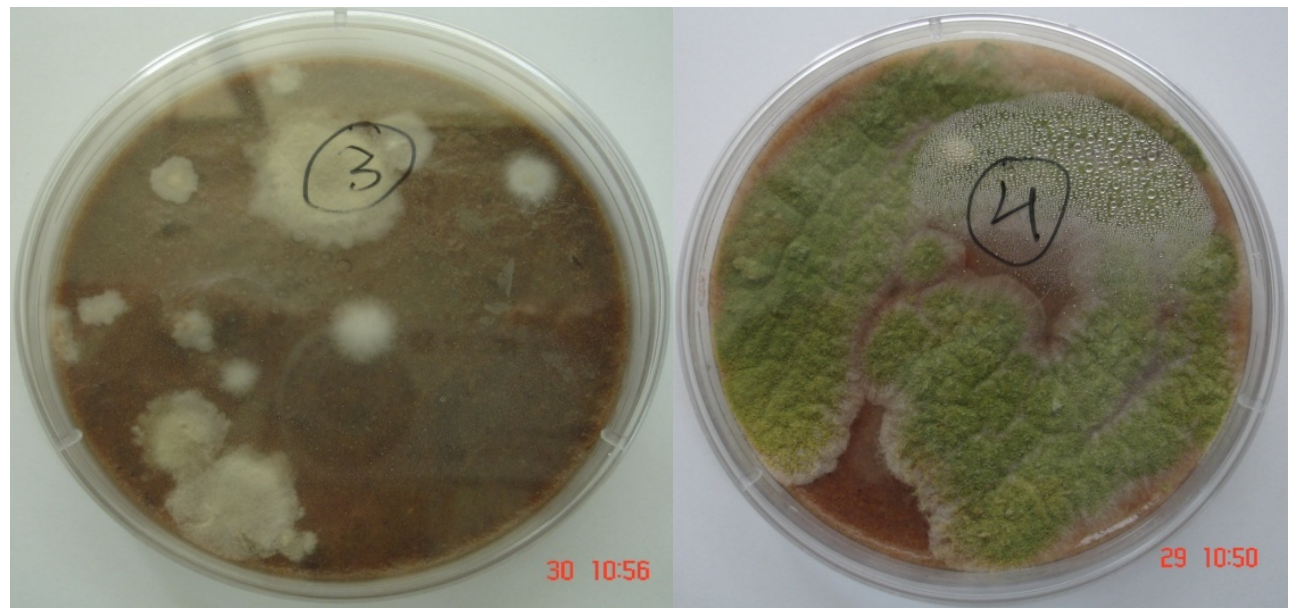

Thermomyces lanuginosus

Aspergillus oryzae

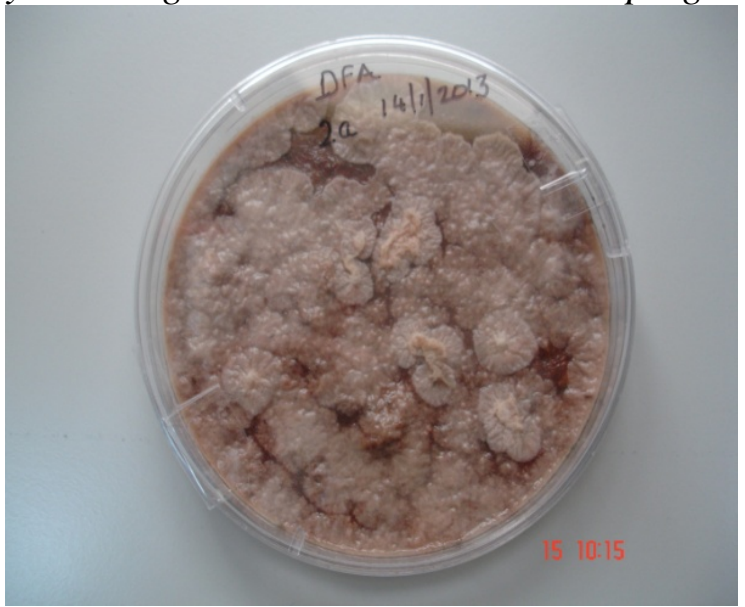

Fusarium graminearum

Fig. 1. Growth of the five fungal strains. 


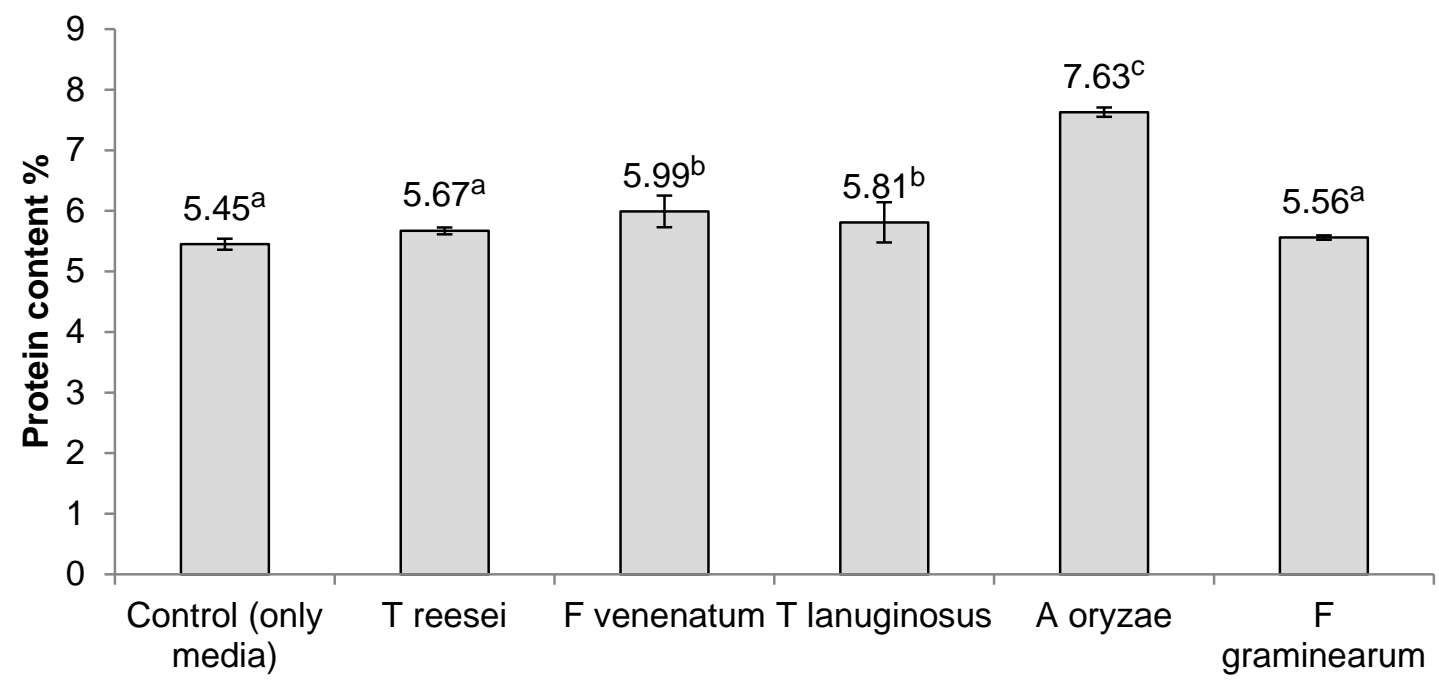

Strains

Fig. 2. Protein content (\%) produced by different fungal strains. The values followed by the same letters are not significantly different $(p<0.05)$.

Nitrogen source

In order to select the optimum nitrogen source for maximum fungal growth, three nitrogen sources, ammonium chloride, ammonium sulfate and urea were used. Figure 3 present the effect of nitrogen source on protein content produced by $A$. oryzae after 5 days growth. The result shows that ammonium sulfate was the best source as the protein content produced was significantly highest (13.8\%). Rao et al [19] also found ammonium sulfate is the best nitrogen source for fungi strain Penicillium janthinellum to produce SCP from bagasse. The possible reason may be that ammonium sulfate has some additional growth factors such as some amino acids, mineral, certain vitamins, which gave better growth results compare to other nitrogen sources [13]. This source is rather inexpensive and easy to mix with the media. Therefore, ammonium sulfate was selected as the optimal nitrogen source for A. oryzae growth on DWA medium. However, Mondal et al [3] found inorganic nitrogen supplementation had suppressive effect by decreasing SCP produced by yeast.

\section{Concentration of nitrogen source}

The selected ammonium sulfate was used in different concentration to determine the optimum concentration for $A$. oryzae growth on DWA medium. Figure 4 shows the effect of difference concentration of ammonium sulfate on protein content produced by A. oryzae. The protein content increased with increase of ammonium sulfate to reach to maximum content when using $1 \%$ ammonium sulfate. However, the difference between 0.8 and $1.0 \%$ concentration was insignificant, therefore, $0.8 \%$ ammonium sulfate was selected as the optimum concentration for growth medium. This result supported by Ahangi et al $[18,20]$, they found that lower glucose level and higher nitrogen level in fungi medium resulted higher protein production. 


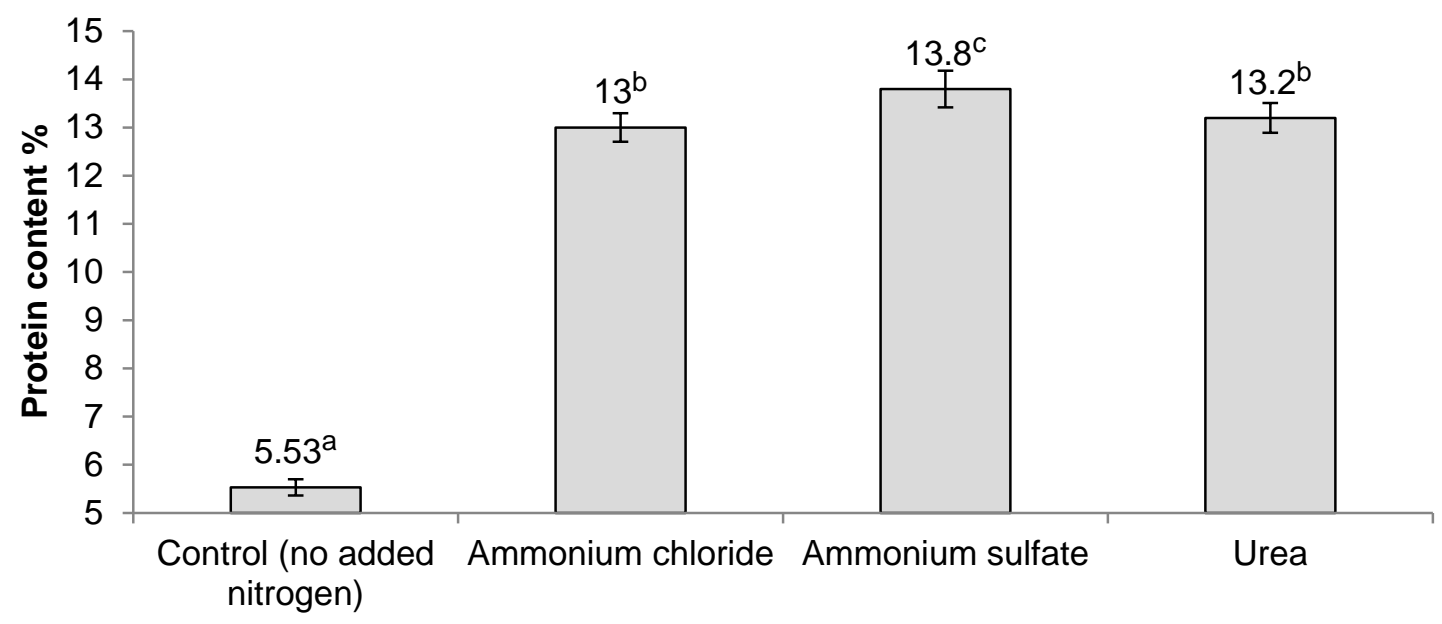

Nitrogen source

Fig. 3. Effect of nitrogen source on protein content (\%) produced by Aspergillus oryzae in dates waste agar (DWA). The values followed by the same letters are not significantly different $(p<$ 0.05).

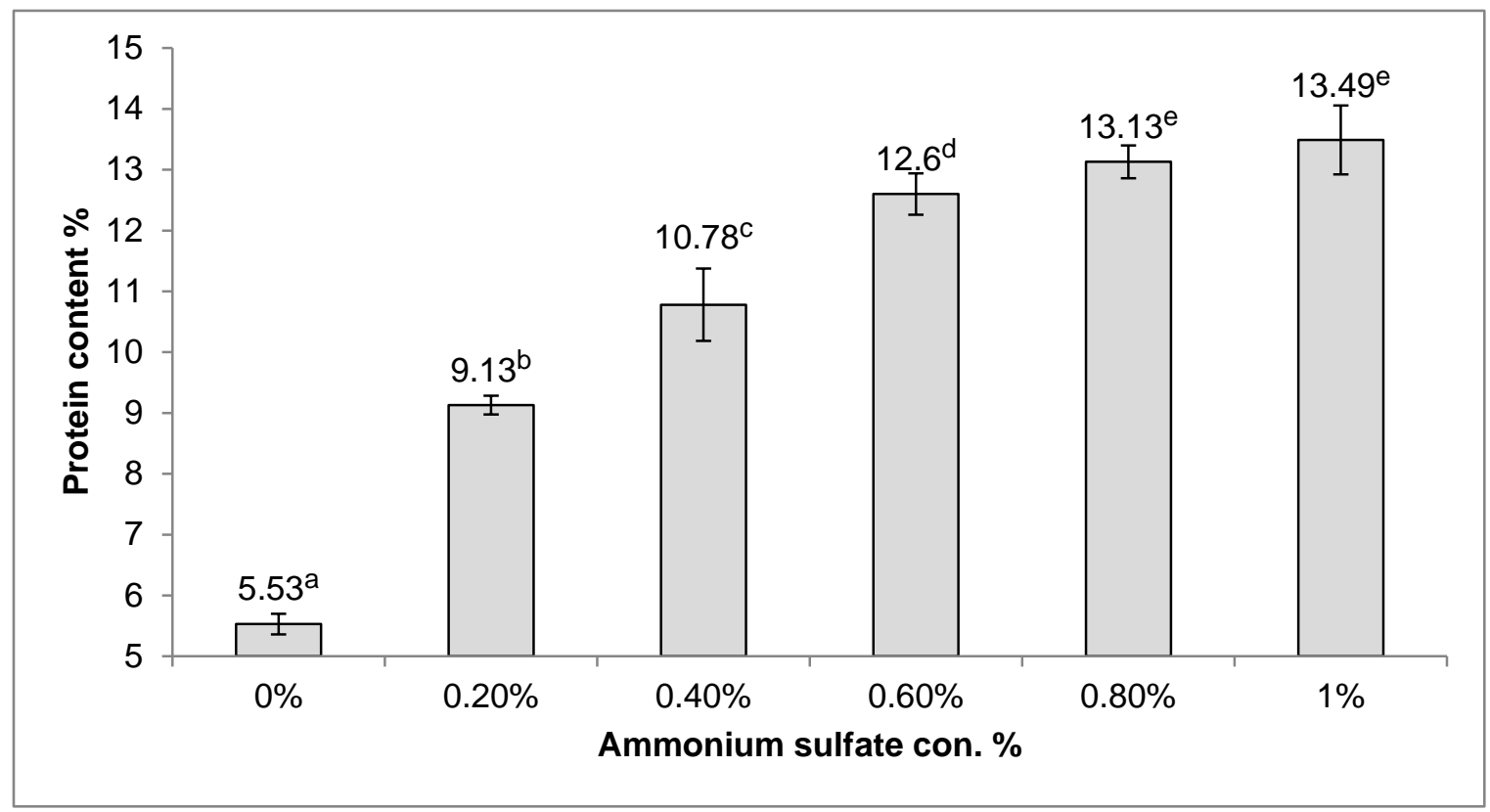

Fig. 4. Effect of ammonium sulfate concentrations (\%) on protein content (\%) produced by Aspergillus oryzae in dates waste agar (DWA). The values followed by the same letters are not significantly different $(p<0.05)$.

Medium weight / flask volume ratios

Figure 5 presents the effect of various medium weight/flask volume ratio on protein content produced by A. oryzae. Protein content obtained from different substrate levels revealed that $75 \mathrm{~g}$ in $250 \mathrm{ml}$ flask was the best ratio for growth. Therefore, the ratio of $75 \mathrm{~g} / 250 \mathrm{ml}$ was selected as the optimal ratio. This factor is important in estimating the required media quantities according to the fermentation vessel volume. The substrate cost is the largest single cost factor in SCP 
production, thus, simplifying the manufacture and purification of substrate can reduce cost production.

\section{Medium $p H$}

The initial $\mathrm{pH}$ of the DWA medium was sensitive to the growth of $A$. oryzae. Different initial $\mathrm{pH}$ values were used to check the optimum $\mathrm{pH}$ value for maximum yield of the biomass. The results of present study showed in Figure 6 that yield of biomass increased from $\mathrm{pH} 4$ and optimum production was observed at 5.5 yielding $16.25 \%$ of crude protein. This $\mathrm{pH} 5.5$ is close range of natural date fibers $\mathrm{pH}$ (5.3). Further increase in initial medium $\mathrm{pH}$ leads to decline in protein production. These results supported by several studies; Ravinder et al [19-21] found the optimal growth of $A$. oryzae in rice bran was in $\mathrm{pH}$ range of 5-7. Jin et al $[16,17]$ found $\mathrm{pH} 4.5-5.5$ was the optimum $\mathrm{pH}$ for A. oryzae in starch waste water. Also, Yousufi [20-22] reported pH 5.0 as the optimum $\mathrm{pH}$ for production of SCP from soymilk using A. oryzae.

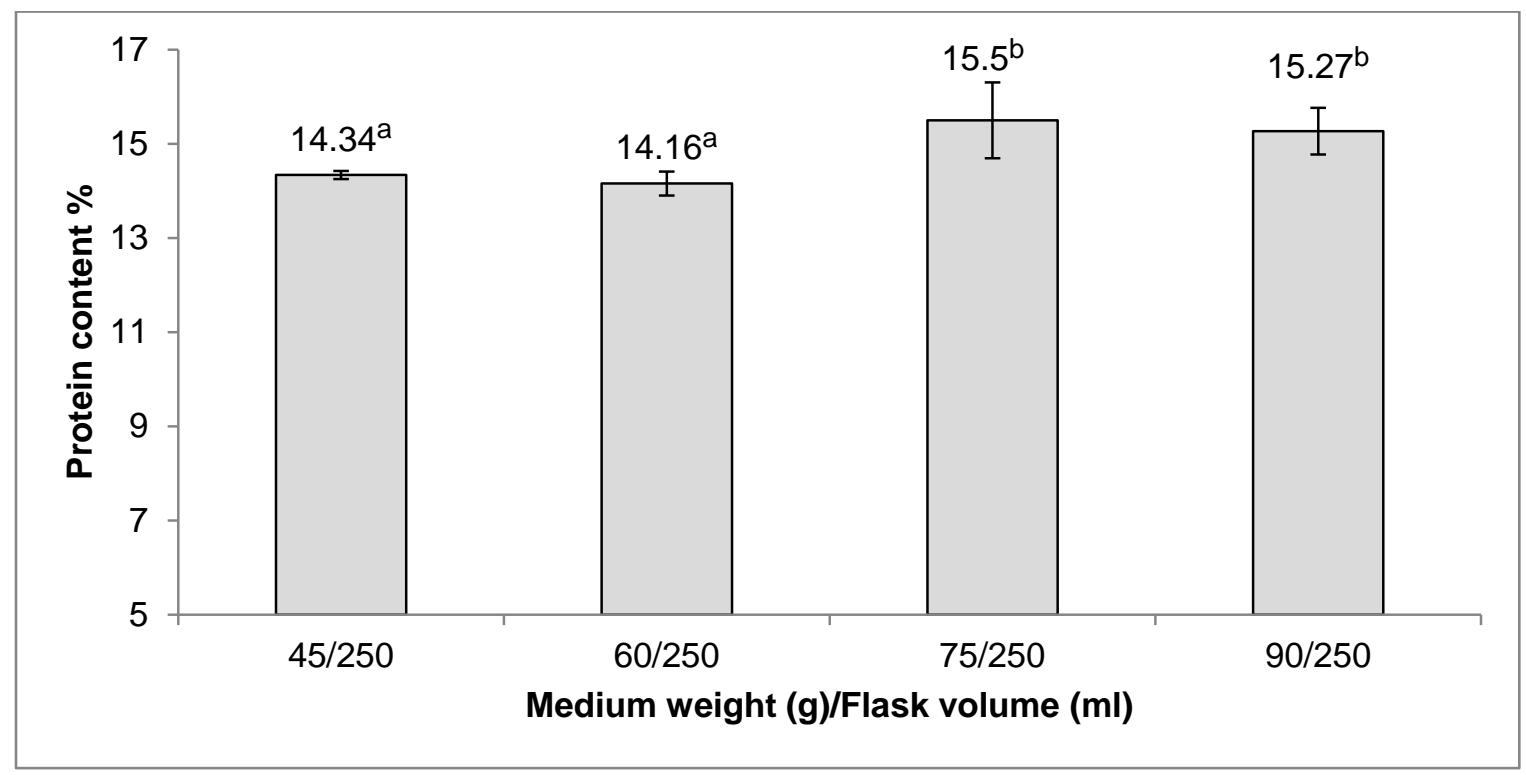

Fig. 5. Effect of various medium weight / flask volume ratios on protein content (\%) produced by Aspergillus oryzae in dates waste agar (DWA). The values followed by the same letters are not significantly different $(p<0.05)$. 


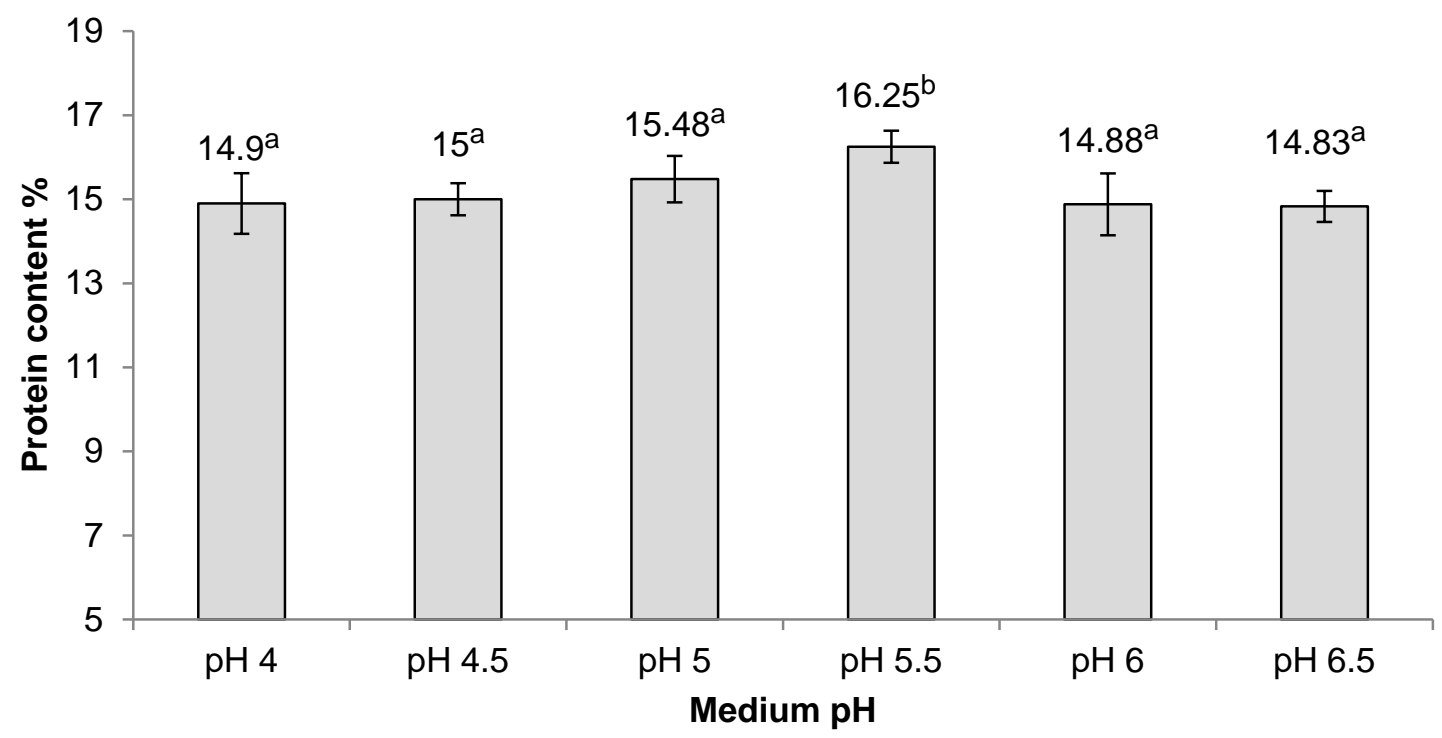

Fig. 6. Effect of medium $p H$ values on protein content (\%) produced by Aspergillus oryzae in dates waste agar (DWA). The values followed by the same letters are not significantly different

$$
(p<0.05) \text {. }
$$

\section{Amino acid content}

The nutritious value and potency of SCP from any source is based on its composition and should be analyzed for the properties of their components such amino acid profile before the final product is used as food or feed supplementation. Table 1 present the content of amino acids in dates waste and SCP produced by this study. The total content of amino acids in dates waste was $6.02 \%$ and $10.14 \%$ in SCP. Glutamic, aspartic and proline acids were the major amino acids in SCP, and their value are 1.11, 1.01 and $0.88 \%$ respectively. The results indicated that the ratio of essential amino acids to total amino acids of the SCP produced was $46 \%$, which is a good source of nutrition. Khanifar et al [21-23] reported higher ratio of essential amino acids produced by white rot fungi from wheat straw, which was $65.6 \%$. The nutrition benefits of SCP depend on culture condition, pre-treatment of substrates, nutrient supplementation, types of fermentation processes and strain [22-24]. 
Table 1. Amino acids content (\%) of dates fiber and single cell protein (SCP) from dates waste

\begin{tabular}{|c|c|c|}
\hline Amino acids \% & Date fiber & SCP \\
\hline Lysine $*$ & $0.28^{\mathrm{a}}$ & $0.48^{b}$ \\
\hline Methionine * & $0.14^{\mathrm{a}}$ & $0.22^{b}$ \\
\hline Cystine & $0.11^{\mathrm{a}}$ & $0.19^{b}$ \\
\hline Aspartic acid & $0.64^{\mathrm{a}}$ & $1.01^{\mathrm{b}}$ \\
\hline Threonine * & $0.31^{\mathrm{a}}$ & $0.52^{b}$ \\
\hline Serine & $0.35^{\mathrm{a}}$ & $0.58^{b}$ \\
\hline Glutamic acid & $0.74^{\mathrm{a}}$ & $1.11^{\mathrm{b}}$ \\
\hline Proline & $0.30^{\mathrm{a}}$ & $0.88^{b}$ \\
\hline Glycine & $0.42^{\mathrm{a}}$ & $0.63^{b}$ \\
\hline Alanine & $0.43^{\mathrm{a}}$ & $0.68^{b}$ \\
\hline Valine $*$ & $0.37^{\mathrm{a}}$ & $0.57^{b}$ \\
\hline Isoleucine * & $0.27^{\mathrm{a}}$ & $0.44^{\mathrm{b}}$ \\
\hline Leucine $*$ & $0.53^{\mathrm{a}}$ & $0.85^{b}$ \\
\hline Tyrosine & $0.22^{\mathrm{a}}$ & $0.22^{\mathrm{a}}$ \\
\hline Phenylalanine * & $0.30^{\mathrm{a}}$ & $0.72^{b}$ \\
\hline Histidine * & $0.16^{\mathrm{a}}$ & $0.28^{b}$ \\
\hline Arginine * & 0.32 & $0.57^{b}$ \\
\hline Tryptophan & $0.13^{\mathrm{a}}$ & $0.19^{b}$ \\
\hline Total & $6.02^{a}$ & $10.14^{b}$ \\
\hline
\end{tabular}

* The essential amino acids. Values followed by the same letter, within a row, are not significantly different $(p<0.05)$.

\section{Conclusions}

Optimization of SCP production from dates waste using fungal strains been conducted. From the five fungal strains used, A. oryzae was the best with the optimized condition of; ammonium sulfate at $0.8 \%$ as nitrogen source, $75 \mathrm{~g}$ of medium in $250 \mathrm{ml}$ flask and at $\mathrm{pH}$ of 5.5 . The SCP produced was a good source of nutrition as the ratio of essential amino acids to the total amino acids reach $46 \%$. This preliminary study provides the optimum conditions for producing SCP from date's waste, which is useful for large scale industry.

\section{References}

[1] M.J. Asad , M. Asghan, M. Yaqub, K. Shahzad, Production of single cell protein delignified corn cob by Arachniotus species, Pak. J. of Agric. Sci. 37 (2000) 3-4.

[2] P. Jamel, M.Z. Alam, N. Umi, Media optimization for bio proteins production from cheaper carbon source, J. of Engi. Sci. and Techno. 3-2 (2008) 124-130.

[3] A. Mondal, S. Sengupta, J. Bhowal, D. Bhattacharya, Utilization of fruit wastes in producing single cell protein, International Journal of Science Environment \& Technology, 1-5 (2012) 430438.

[4] A.T. Nasseri S. Rasoul-Amini, M.H. Morowvat, Ghasemi, Single cell protein: Production and process, Ame. J. Food Technol. 6 (2011) 103-116. https://doi.org/10.3923/ajft.2011.103.116 
[5] N.M. Nigam, Cultivation of Candida langeronii in sugarcane bagasse hemi cellulose hydrolysate for the production of single cell protein, W.J.Microbiol and biotechnol. 16 (2000) 367- 372.

[6] H. Tipparat, A.H. Kittikun, Optimization of single cell protein production from cassava starch using Schwanniomyces castellii, W.J. Microbiol. \& Biotechnol. 11 (1995) 607-609. https://doi.org/10.1007/bf00360999

[7] S.A.A. Abou Hamed, Bioconversion of wheat straw by yeast into single cell protein, Egypt, J. Microbiol. 28-1 (1993) 1-9.

[8] P.M.A. Saquido, V.A. Cayabyab, F.R. Vyenco, Bioconversion of banana waste into single cell protein, J. Applied Microbiol. \& Biotechnol. 5-3 (1981) 321-326.

[9] G. Zhao, W. Zhang, G. Zhang, Production of single cell protein using waste capsicum powder produced during capsanthin extraction, Lett Appl Microbiol. 50 (2010) 187-91. https://doi.org/10.1111/j.1472-765x.2009.02773.x

[10] M.E. Smith, A.T. Bull, Protein and other compositional analysis of Saccharomyces fragilis grown on coconut water waste, J. Applied Bacteriol. 41 (1976) 97-107.

[11] M. Al-Farsi, C. Alasalvar, M. Al-Abid, K. Al-Shoaily, M. Al-Amry and F. Al-Rawahy, Compositional and functional characteristics of dates, syrups and their by-products, Food Chem. 104(2007) 943-947. https://doi.org/10.1016/j.foodchem.2006.12.051

[12] Al Barakah Date Company, Al Barakah Dates (2016): www.albarakahdatesfactory.com, accessed 11th March 2019.

[13] M.A. Shahzad, M. Rajok, Single cell protein production from Aspergillus terreus and its evaluation in broiler chicks, Int. J. Biosci. Biochem. Bioinform. 1 (2011) 137-141.

https://doi.org/10.7763/ijbbb.2011.v1.25

[14] D. Dhanasekaran, S. Lawanya, S. Saha, N. Thajuddin and A. Panneerselvam, Production of single cell protein from pineapple waste using yeast, Innovative Romanian Food Biotechnol. 8 (2011) 26-32.

[15] D.N. Kamara, F. Zadrazil, Microbiological improvement of lignocellulosic in animal feed production: Rrview. Elsevier, Essex, UK (1988) 56-63.

[16] EU., The official European union regulation no. 152/2009. Official Journal of the European Union (2009) 23-31.

[17] B. Jin, H.J. Van Leeuwen, B. Patel, Q. Yu, Utilization of starch processing wastewater for production of microbial biomass protein and fungal alph-amylase by Aspergillus Oryzae.

Bioresource Technology 66 (1998) 201-206. https://doi.org/10.1016/s0960-8524(98)00060-1

[18] R. Ravinder, L. Venkateshwar, P. Ravindra , Studies on Aspergillus oryzae Mutants for the Production of Single Cell Proteins from Deoiled Rice Bran. Food Technol. Biotechnol. 41-3 (2003) 243-246.

[19] M. Rao, A. Varma, S. Deshmukh, Production of single cell protein, essential amino acids and xylanase by Penicillium janthinellum. BioResource 5 (2010) 2470-2477. 
[20] Z. Ahangi, S.A. Shojaosadati, H. Nikoopour, Study of mycoprotein production using Fusarium oxysporum PTCC 5115 and reduction of its RNA content, Pakistan. J. Nutr.7 (2008) 240-243. https://doi.org/10.3923/pjn.2008.240.243

[21] R. Ravinder, L. Venkateshwar Rao, P. Ravindra, Production of SCP from de-oiled rice bran, Food Technol. Biotechnol. 41 (2003) 243-246.

[22] M.K. Yousufi, Impact of $\mathrm{pH}$ on the single cell protein produced on okara-wheat grit substrates using Rhizopus oligosporus and Aspergillus Oryzae, J. Envir. Sci. Tox. Food Tech 1-2 (2012) 32-35. https://doi.org/10.9790/2402-0123235

[23] J. Khanifar, H. Ghoorchian, A.R. Ahmadi, R. Hajihosaini, Comparison of essential and non essential amino acids in the single cell protein of white rot fungi from wheat straw, Afri. J Agri. Rese. 6-17 (2012) 3994-3999.

[24] Anupama, P. Ravindra, Value-added food: Single Cell Protein. Biotechnol. Advances 18 (2000) 459-479. https://doi.org/10.1016/s0734-9750(00)00045-8 